\title{
Impact of cryoprotection on minimization of ascorbic acid losses in freezing of berries
}

\author{
Galyna Simakhina, Nataliya Naumenko, \\ Svitlana Bazhaj-Zhezherun, Svitlana Kaminska
}

National University of food Technologies, Kyiv, Ukraine

\section{Keywords:}

Berry
Freezing
Cryoprotector
Defrosting
Vitamin

Article history:

Received

10.10.2018

Received in revised

form 21.02.2019

Accepted

31.05.2019

\section{Corresponding}

author:

Galyna Simakhina

E-mail:

lyutik.0101@

gmail.com

DOI:

$10.24263 / 2304-$

974X-2019-8-2-7

\section{Abstract}

Introduction. Minimization of ascorbic acid losses during freezing and frozen storage of berries can be achieved by various methods of cryoprotection. The objectives of this research are to confirm the impact of different cryoprotectors on minimization of ascorbic acid losses during freezing and frozen storage of berries.

Materials and methods. Bilberries, blackberries, and chokeberries in fresh, frozen and defrosted states were researched in this article. The 10-percent solutions of mono and disaccharides, the 1percent solutions of organic acids and the 15-percent solution of inorganic salt (magnesium chloride) were chosen as cryoprotectors. The amount of ascorbic acid in defrosted berries, which was defined by the well-known method (with sodium 2.6-dichlorphenolindofenolate), was the criterion to confirm the effectiveness of cryoprotectors.

Results and discussion. The traditional methods to freeze the berries had proved the well-known fact of the significant losses of ascorbic acid. The latter made up 16.8 to 26.3 percents in frozen products and 55.6 to 71.0 percents in those defrosted. This was the result of cryogenous damages of berries' cells by ice crystals, and thereinafter the cause of ascorbic acid oxidation by oxidoreductases and its leakage together with cellular juice during berries' defrosting.

The berries processed with cryprotective solutions before freezing were believed to keep the holity of their structure during freezing, longterm (for 12 months) frozen storage, and defrosting. Therefore, the effect of ascorbic acid retention in most cases exceeded 80 percents, relatively to its amount in fresh raw materials. Thanks to protective action of cryoprotectors at the stage of berries freezing, the ascorbic acid losses did not overcome 16.8 to 26.3 percents; after frozen storage for 12 months and defrosting, the residual amount of ascorbic acid made up 62.8 to 83.5 percents. Meanwhile, the control samples (berries frozen without protectors) had got ascorbic acid left on the level of 22.4 to 33.6 percents.

The authors of this article proposed to classify the cryoprotectors by four categories according to their cryoprotective effect (relatively to ascorbic acid); the cryoprotectors which showed the effect of ascorbic acid retention less than 40 percents were not recommended to further usage. The compound cryoprotectors turned to be more effective than those simplex. Only the berries frozen by the improved method (with cryoprotectors) had received the highest grade (5 out of 5) by all of the indices.

Conclusions. Realization of theoretical knowledge in studying the cryoprotectors by cryobiology scientists had shown the positive effect of cryoprotection in berries freezing. 


\section{Introduction}

According to the prognoses by analytics, the demand for frozen fruit-and-berry and vegetable products is growing constantly in the entire world, and the amount of their consumption is increasing on almost 4 percents [1,2]. It is the regulation proved.

The usage of artificial cold causes minimal changes in nutritional and biological value of the raw materials and foodstuffs obtained from them, in their quality and sensory indices [3]. Along with that, the method to preserve the food materials by freezing, regarding its economy and specific energy supply, has got some significant advantages in comparison with methods of thermal preservation (pasteurization, sterilization, drying etc.) [4].

This is no wonder that the specialists in food science give priority to the method of cold preservation of raw materials and final foodstuffs, in all of its modifications and variants of the usage $[5,6,7]$.

Meanwhile, in Central and East Europe the domestic frozen plant products are not yet issued in reasonable amounts [8], especially fruit and berries; those sold at the markets are mostly of low quality due to disadvantages in the traditional methods of freezing and frozen storage of half products [9]. Biological objects are often exposed to significant cryogenous damages during freezing $[8,9]$; consequently, cellular juice and all the biologically active substances that it contains (vitamins, mineral elements, minor components as the valuable constituents of fruit-and-berry raw material) get lost in defrosting [10].

Henceforth, the improvement of the existent low-temperature technologies of fruit, berry, and vegetable raw procession (particularly, due to the combination of the impact of cold with other physical and technological factors) is relevant for the producers of frozen half products $[11,12,13]$.

The analysis of up-to-date scientific works on the topic of our research evidences that the mechanisms of cryogenous damages of plant cells and the methods to protect the latter are studied profoundly in cryobiology $[14,15]$ which is comparatively young branch of general biology. Our studies of fundamental and applied researches accomplished in the 1950s-1970s at the cryobiological centers of USA, Great Britain, France, Japan etc. allowed generalizing the results of the first endeavors in cryobiology. They were further developed in the works by R.A. Carrow [16] who studied the behavior of different parts of the live cell in freezing; A. Bilous and V. Gryshhenko [9] who researched the problems of cryogenous preservation of reproductive cells; Ye. Gordiyenko [17] who dedicated his works to the lowtemperature preservation of cellular suspensions.

The general conclusion is the following: the development of destructive crystal making (both inside and outside the plant cells) can be crucially slowed down if the freezing of cells and tissues goes on with a help of various cryoprotectors which benefit the modification of liquid phase structure and the character of crystal making.

Because the natural biological objects in medical and agricultural raw materials are similar by chemical composition and cell structure, it is expedient to use the experience gained by aforesaid theorists in food technologies. The number of the works published is small enough $[11,18]$; therefore, each new research in this trend will contribute to the development and usage of the novel effective methods of freezing whose main destination is the retention of the maximal amounts of biologically active substances (ascorbic acid, first of all, as the most liable component) from raw materials in the final product.

The objectives of this research is to study the cryoprotective abilities of various compounds of both organic and mineral origin from the viewpoint of minimization of ascorbic acid losses during freezing, frozen storage, and defrosting of berries. 


\section{Materials and methods}

\section{Plant raw materials}

We conducted the researches with bilberries, blackberries and chokeberries. After selection, washing, and contaminant removal, all of the researched specimens were processed with cryoprotective solutions of both organic and mineral origin, which were thoroughly described in the works on cryobiology $[9,14,17]$ and thenceforth proved in our studies.

\section{Cryoprotective solutions}

Among over 20 different cryoprotective compounds, we chose mono and disaccharides (glucose, fructose, and sucrose), organic acids (citric, sorbic, and benzoic), and magnesium chloride for our research. The preliminary studies had shown the expedience to use of cryoprotective solutions with 10 and 15-percent concentration, and also the higher effectiveness of compound protectors [19]. Therefore, we grounded the compositions of cryoprotectors with the following proportions: sucrose (10 percents) and citric acid (1 percent); glucose (10 percents) and citric acid ( 1 percent); fructose (10 percents) and citric acid (1 percent); sorbic acid (1 percent) and benzoic acid (1 percent), and also simplex cryoprotectors - magnesium chloride (15 percents), sucrose (10 percents), glucose (10 percents), and fructose (10 percents).

\section{Obtaining the frozen berries}

After acceptation, washing, and contaminant removal, the berries were processed by cryoprotective solutions during 40-60 $\mathrm{min}$ at the room temperature. Then, they were frozen scattered in rapid freezer at the temperature of $-35-37^{\circ} \mathrm{C}$, which corresponded to the parameters of rapid freezing [20]. The process lasted until the temperature $-18 \pm 1{ }^{\circ} \mathrm{C}$ in the middle of the berries scattered.

Frozen berries were packed into the packages of 500 grams, observing the requirements of package holity and hermetic sealing; stored during 12 months (the maximal term) at the temperature of $-18{ }^{\circ} \mathrm{C}$ and relative humidity of no more than 95 percents. In preparing to freezing, the berries were defrosted at the temperature of $34-40{ }^{\circ} \mathrm{C}$ in the water bath. The berries frozen by the traditional technology, i.e. without cryoprotectors, served the control specimens.

\section{Definition of vitamin $\mathrm{C}$ content}

The content of vitamin $\mathrm{C}$ is the main biologically active component of the berries to determine their nutritional and biological value. That is why the level of its retention is the probable indicator to expose the perfection of the freezing technology. This index was defined in berries fresh, frozen and defrosted by the traditional technology (control), and frozen with a help of cryoprotectors. The method of vitamin C definition is well-known and based on the usage of sodium 2.6-dichlorphenolindofenolate [21].

\section{Evaluation of sensory indices of fresh and frozen berries}

Having based on the literary data and the results of our own researches, we widened the interpretations of the characteristics for sensory properties of fresh fruit, berries, and frozen half products made of them in order to give them the proper objectivity. That resulted in elaboration of five-point scale to evaluate every index, which would increase the requirements to the raw materials and guarantee the high quality of frozen products during the entire storage term and further defrosting [22]. The frozen products are supposed to 
slightly differ from fresh raw by their sensory indices and qualitative composition (this should be the main criterion of perfection of the novel freezing technology). Thenceforth, we firstly presented the characteristics of both raw materials and the frozen half products obtained from them (Figure1).

Methods to evaluate the main sensory indices of fresh and frozen berries

Figure 1

\begin{tabular}{|c|c|c|}
\hline Index & $\begin{array}{c}\text { Research } \\
\text { subjects }\end{array}$ & Characteristics \\
\hline \multirow[t]{2}{*}{ Appearance } & fresh & $\begin{array}{l}\text { clean, fresh, with stems (blackberries), without stems } \\
\text { (bilberries and chokeberries), homogenous in maturity, with } \\
\text { wax plaque, and with proper shape }\end{array}$ \\
\hline & frozen & $\begin{array}{l}\text { clean, frozen, with bluish plaque, turgid, not squashed, and } \\
\text { with proper shape }\end{array}$ \\
\hline \multirow[t]{2}{*}{ Taste } & fresh & $\begin{array}{l}\text { immanent to the certain species, with the taste sour, sweet, } \\
\text { astringent, slightly bitter, or spicy (or their combinations) }\end{array}$ \\
\hline & frozen & $\begin{array}{l}\text { immanent to the certain species, with the taste sour, sweet, } \\
\text { astringent, slightly bitter, or spicy; the taste may slightly } \\
\text { vary due to the chill stress }\end{array}$ \\
\hline \multirow[t]{2}{*}{ Color } & fresh & $\begin{array}{l}\text { immanent to the certain species, correspondent to harvest } \\
\text { maturity; the color intensity is defined as the maturity } \\
\text { marker }\end{array}$ \\
\hline & frozen & $\begin{array}{l}\text { immanent to the certain species; with no declinations from } \\
\text { the natural color; the color intensity may increase due to } \\
\text { anthocyanine synthesis as the reaction to the chill stress }\end{array}$ \\
\hline \multirow[t]{2}{*}{$\begin{array}{l}\text { Surface } \\
\text { state }\end{array}$} & fresh & $\begin{array}{l}\text { dry, clean, without illnesses, damages, and signs of } \\
\text { withering; dependently on the pomological sort, may be } \\
\text { moistened; with harvest maturity and the proper color; the } \\
\text { peel is dense }\end{array}$ \\
\hline & frozen & $\begin{array}{l}\text { clean, slightly moistened, naturally turgid, without damages } \\
\text { of the peel and cellular juice losses }\end{array}$ \\
\hline \multirow[t]{2}{*}{ Odor } & fresh & proper to the certain species (light, strong, subtle, tender) \\
\hline & frozen & $\begin{array}{l}\text { proper to the certain species (light, strong, subtle, tender); } \\
\text { may be gained as the result of the chill stress }\end{array}$ \\
\hline
\end{tabular}

Afterwards, the mentioned sensory characteristics of the berries were evaluated by the five-point scale elaborated by the authors of this article. The ' 5 ' grade was given to the berries clean and fresh; of the intensive color; with clean surface, without defects and damages; with the intensive odor immanent to the certain species. The '4' grade was given to the berries clean and fresh, without defects and damages (up to 5 percents of immature berries); with slightly perceptible strange smack and odor; of the color immanent to the certain species; with clean low-mat surface. The ' 3 ' grade was given to the berries clean, fresh, without defects and damages (up to 7 percents of immature berries); with stable strange smack and odor; of low-intensive color.

The berries that have got the ' 1 ' and ' 2 ' grades are not recommended for freezing. These are faded berries, not homogenous in shape, with defects (up to 10 percents of non-standard items); with unpleasant strange smack and odor, significant damages of the surface, the symptoms of negative biochemical processes (even rotting), and the natural color lost. 


\section{Results and discussion}

\section{Ascorbic acid in the berries fresh and frozen traditionally}

The research got started from the evaluation of shifts of the ascorbic acid amount during freezing the berries by the traditional method, their frozen storage and defrosting. The results are presented in Figure 2.

Figure 2

Dynamics of shifts of the ascorbic acid amount in the berries frozen traditionally

\begin{tabular}{|l|c|c|c|c|}
\hline \multirow{2}{*}{\multicolumn{1}{|c|}{ Specimens to research }} & \multicolumn{2}{|c|}{$\begin{array}{c}\text { Ascorbic acid amount in the berries, mg } \\
\text { per100 g }\end{array}$} & \multirow{2}{*}{ HIP } \\
\cline { 2 - 4 } & Blackberries & Chokeberries & Bilberries & \\
\hline Fresh berries & 130.4 & 243.6 & 193.3 & 0.8 \\
\hline Frozen berries (control) & 104.9 & 202.0 & 142.5 & 0.7 \\
\hline $\begin{array}{l}\text { Frozen and defrosted berries } \\
\text { (control) }\end{array}$ & 48.5 & 108.1 & 56.1 & 0.9 \\
\hline
\end{tabular}

The analysis of the figure data showed that the berries rapidly frozen by the traditional technology had already lost the certain amount of ascorbic acid. If to take its content in fresh berries for 100 percents, it got lowered on 19.6 percents in frozen blackberries, on 16.8 percents in chokeberries, and on 26.3 percents in bilberries. This was the result of destructive impact of extra and intracellular ice crystals on cellular membranes and subcellular structures. Consequently, the number of cells got destroyed, the cytoplasm membrane (or cellular carcass) got torn [23], and this all lead to the direct contacts between biologically active substances inside the cells and oxidoreductases. The latter enhanced the biochemical reactions of oxidation, leading to ascorbic acid decomposition.

Ascorbic acid losses got significantly increased during the berries' defrosting, due to the leakage of cellular juice from cryogenously damages cells, together with biologically active components dissolved in it. For example, this index has grown up to 62.8 percents in blackberries; 55.6 percents in chokeberries; 71.0 percents in bilberries. As a result, the nutritional and biological value of half products has sharply fallen, and thus the final products are believed to be hardly obtained from even the most qualitative raw materials.

The data from Figure 2 allowed concluding that the amount of vitamin $\mathrm{C}$ is different in various berries with similar conditions of freezing and defrosting. Undoubtedly, it is connected with qualitative and quantitative biocomponents' content, besides the factors mentioned above, and is the evidence of the direct correlation between the level of vitamin retention and the amount of sugars in the berries. This all can correspond with well-known theoretical data from cryobiology [9]: glucose, fructose, and sucrose are the natural cryoprotectors. For example, bilberries have the less content of sugars than blackberries and chokeberries, and therefore the level of ascorbic acid retention is lower. The berries' holity also depends on the structure and density of peel which makes them able to resist the cryogenous damages [24, 25]. 


\section{Ascorbic acid in defrosted berries beforehand frozen with cryoprotectors}

The comparison of the residual amount of ascorbic acid in the berries frozen with cryoprotectors and defrosted after the 12-month storage allowed us to answer several questions simultaneously. First of all, the question was how to evaluate the positive impact of cryoprotection on retention of the most precious and liable component (which is vitamin C) in defrosted half products. The second problem was the effectiveness of using either the complex or combined cryoprotector to freeze various biological objects. Finally, the third point was to prove the real possibility to choose the proper cryoprotector for different sort of raw fruit and berries to provide its maximal cryoprotection and thereto the minimal ascorbic acid losses.

Figure 3 represents the calculation of the amount of ascorbic acid (in percentage to the mentioned index in fresh berries): blackberries contain $130.4 \mathrm{mg} / 100 \mathrm{~g}$; chokeberries contain $243.6 \mathrm{mg} / 100 \mathrm{~g}$; bilberries $193.3 \mathrm{mg} / 100 \mathrm{~g}$. These indices are obtained in the berries frozen by the improved technology (with cryoprotectors) and defrosted after the 12month storage.

Residual amount of ascorbic acid in defrosted berries

Figure 3

\begin{tabular}{|l|c|c|c|}
\hline \multirow{2}{*}{ Cryoprotector } & \multicolumn{3}{c|}{$\begin{array}{c}\text { The residual amount of ascorbic acid, } \\
\text { percents to its content in fresh berries }\end{array}$} \\
\cline { 2 - 4 } & Blackberries & Chokeberries & Bilberries \\
\hline $\mathrm{MgCl}_{2}(15 \%)$ & 76.8 & 70.7 & 62.4 \\
\hline Sucrose (10\%) & 78.7 & 76.5 & 64.0 \\
\hline Fructose (10\%) & 64.9 & 63.8 & 58.8 \\
\hline Glucose (10\%) & 75.8 & 64.2 & 57.7 \\
\hline Sucrose (10\%) + citric acid (1\%) & 83.5 & 81.8 & 75.5 \\
\hline Fructose (10\%) + citric acid (1\%) & 74.2 & 70.4 & 64.7 \\
\hline Glucose (10\%) + citric acid (1\%) & 81.6 & 69.8 & 76.5 \\
\hline Sorbic acid (1\%) + benzoic acid (1\%) & 62.8 & 60.5 & 58.4 \\
\hline Control (without cryoprotectors) & 31.0 & 33.6 & 22.4 \\
\hline
\end{tabular}

According to the data of the Figure 3, the positive influence of cryoprotectors was displayed in all of the objects: the level of ascorbic acid retention in the berries frozen by the improved technology and defrosted after 12-month storage exceeds the identical index for the berries frozen without cryoprotectors at all the stages of the experiment. Although the mechanisms of cryoprotective action are complicated and have not been yet discovered fully, it is possible to affirm that they would help minimize the results of minus temperatures' destructive impact during freezing and further defrosting of the berries. The data about the residual amount of ascorbic acid are good evidence of this fact.

In spite of the variety of cryoprotectors and their combinations chosen for the research, their influence on the objects studied has got its regulations. Having based on the theoretical data existing by now [See 26], we may say that the main point in activity of the cryoprotectors 
is their ability to reduce the amount of water which can crystallize during freezing (and thereby to reduce the number of large ice crystals), to benefit the creation of small-crystal ice, and, subsequently, to protect the cell from the pernicious impact of minus temperatures.

The authors [7] supplemented this theory by the deductions about the cryoprotectors' ability to lower the freezing point of water (cryoscopic temperature); to gain the viscosity of solutions and therefore to retard the growth of ice crystals; to influence positively the processes of hydration of plant cells in defrosting.

Thenceforth, the authors of this article discovered that the positive impact of cryoprotectors usage in the technologies to freeze the raw berries (particularly, from the viewpoint of maximal retention of ascorbic acid) was the result of the combination of several aforesaid effects shown by researched cryoprotectors.

As for A. Belous and V. Gryshhenko, the leading specialists in cryobiology and cryomedicine [6], the cryoprotectors are to be chosen empirically, individually for each of the biological objects, because the universal principles to select the cryoprotector with the properties programmed for the certain object are not elaborated yet. According to Figure 4, the combined cryoprotectors are more effective than those simplex. The highest cryoprotective effect gets achieved in combination of sucrose (10-percent solution) and citric acid (1-percent solution): after 12-month frozen storage and further defrosting, blackberries and chokeberries retain over 80 percents of ascorbic acid, and bilberries retain 75.5 percents. Citric acid in the compound cryoprotectors serves as the polyfunctional substance to change the character of water crystallization in cells and intercellular space, and to support the stability of the structural-functional parameters in biological objects, as the authors [27] confirmed.

Generally, the vitamin value of the berries frozen with cryoprotectors is high enough; otherwise, this effect could not be reached with the traditional freezing technology. The data of Figure 4 eloquently show that the residual amount of ascorbic acid in the berries frozen without cryoprotectors oscillates from 22.4 to 33.6 percents of its content in the raw materials.

The similar regulation was noticed by other researchers. For example, Estonian scientists A. Noormets with co-authors (2006) indicated the influence of different conditions of freezing on the ascorbic acid amount in cowberries (Vaccinium sp.) [28]; C. Mullen with coauthors (2002) analyzed the antioxidant properties of frozen and defrosted red raspberries [29]. The positive influence of the preliminary procession of raspberries on the quality of final products during long-term frozen storage was also confirmed in the work [30]. We may also set up the analogy with the results reached by cryobiologists: the authors [31] confirmed the fact that the red blood cells frozen without cryoprotectors had been exposed to significant damages; particularly, 2 percents of them got destroyed completely. The implementation of cryoprotectors into the freezing environment could prevent such processes [14], and the usage of combined protectors could fully eliminate the damages of red blood cells in freezing / thawing cycles [32].

\section{The rating scale to evaluate the cryoprotective effect of the substances researched}

The data obtained by different scientists are the evidence the essential losses of ascorbic acid in raw fruit and vegetables frozen traditionally (without cryoportectors). The authors [33] showed that frozen wild strawberries had lost 60 percents of ascorbic acid, and the authors [34] observed that the percentage of ascorbic acid loss in vegetables had reached 65. These data are compatible with the results received by other Ukrainian specialists, including those from National University of Food Technologies. Actually, all of the results obtained 
are the convincing argument on the favor of the usage of different cryoprotectors in the technologies of the plant raw freezing.

Therefore, the authors of this article elaborated the rating scale of the researched cryoprotectors to use it in practice. The protectors were classified into four categories by the level of ascorbic acid retention (this index was given the virtual name of 'the effect of cryoprotection'):

- First category - the effect of cryoprotection is 80 percents and higher;

- Second category - the effect of cryoprotection is 70-79 percents;

- Third category - the effect of cryoprotection is 60-69 percents;

- Fourth category - the effect of cryoprotection is 40-59 percents.

The substances with the effect of cryoprotection lower than 40 percents are not recommended to the usage as cryoprotectors.

The distribution of the protectors researched by the categories, according to the rating scale, is the following (Figure 4).

Figure 4

Distribution of the cryoprotectors researched by the effect of cryoprotection of the berries in freezing

\begin{tabular}{|l|c|c|c|}
\hline \multirow{2}{*}{ Cryoprotector } & \multicolumn{3}{c|}{ Defrosted berries } \\
\cline { 2 - 4 } & Blackberries & Chokeberries & Bilberries \\
\hline $\mathrm{MgCl}_{2}(15 \%)$ & II & II & III \\
\hline Sucrose (10\%) & II & II & III \\
\hline Fructose (10\%) & III & III & IV \\
\hline Glucose (10\%) & II & III & IV \\
\hline Sucrose (10\%) + citric acid (1\%) & I & I & II \\
\hline Fructose (10\%) + citric acid (1\%) & II & II & III \\
\hline Glucose (10\%) + citric acid (1\%) & I & II & II \\
\hline Sorbic acid (1\%) + benzoic acid (1\%) & III & III & IV \\
\hline Control (without cryoprotectors) & - & - & - \\
\hline
\end{tabular}

The data of Figures 3 and 4 are the evidence that the cryoprotective effect worked not only at the stage of freezing, but also during the long-term frozen storage and defrosting of half products. The combined cryoprotectors sucrose + citric acid and glucose + citric acid turned to be the most effective - their effect of cryoprotection exceeded 80 percents. The combined protector fructose + citric acid came third in effectiveness (the effect of cryoprotection was 64-74 percent). The same effect was shown by simplex protectors sucrose and magnesium chloride.

There was an interesting fact that the same cryoprotector could show the different protective effect for different berries. For example, the compound protector sucrose + citric acid turned to belong to the $1^{\text {st }}$ category by protecting blackberries and chokeberries, and to the $2^{\text {nd }}$ category by protecting bilberries. The obtained results are attractive not only because of the actual positive cryoprotective effect shown, but also thanks to the possibility to find 
the optimal cryoprotector for the certain kind of raw. Therefore, this would help significantly increase the vitamin value of frozen and defrosted half products obtained from any cultivated berries.

In general, we can foresee that the usage of all of the researched protectors would be effective for various fruit and berries. This is because the protectors' effect is on the average higher than 60 percents (by ascorbic acid amount), which is the good result for defrosted biological objects.

\section{Sensory characteristics of frozen berries}

The nomenclature of the indices to evaluate the quality of fruit, berries, and vegetables, regulated by the normative documents, includes mostly their sensory properties [35]. Thenceforth, we evaluated the organoleptic indices of bilberries frozen by both the traditional and the improved (with cryoprotectors) technology in order to obtain the additional index to compare. The results are presented in Figures 5 and 6.

We used our own improved technology [22] which contained the widened interpretations of sensory indices of the biological objects and the five-point scale to evaluate them. Because the appearance is considered the complex index which combines the shape, largeness, maturity grade, freshness, color of the berries and so on [10], we gave it the maximal meaning of the coefficient of weight -0.35 . Moreover, the application of any other criteria of evaluation in case of fruit and berries' disparity to the requirements of the appearance is believed to be inexpedient.

Figure 5

Mark evaluation of sensory indices of bilberries frozen by the traditional technology

\begin{tabular}{|c|c|c|l|}
\hline Indices & $\begin{array}{c}\text { Coefficient of } \\
\text { weight }\end{array}$ & Points & \multicolumn{1}{|c|}{ Characteristics } \\
\hline Appearance & 0.35 & 3 & $\begin{array}{l}\text { The berries are clean, evenly frozen; the } \\
\text { small amount (up to 5ercents) is } \\
\text { deformed with damaged peels; suitable } \\
\text { for short-term storage (for one month) }\end{array}$ \\
\hline Taste & 0.2 & 2 & $\begin{array}{l}\text { The presence of well-expressed strange } \\
\text { smack with further bitter after-taste }\end{array}$ \\
\hline Color & 0.1 & 3 & $\begin{array}{l}\text { The well-expressed discoloration with } \\
\text { insignificant browning of the higher layer }\end{array}$ \\
\hline Surface state & 0.2 & 3 & $\begin{array}{l}\text { The shape of the berries is slightly } \\
\text { changed; the small amount of squashed } \\
\text { specimens (up to 5\%), insignificant level } \\
\text { of cracking with the signs of cellular juice } \\
\text { leakage }\end{array}$ \\
\hline Odor & 0.15 & 4 & $\begin{array}{l}\text { The odor is natural without strange } \\
\text { mixtures, slightly weakened in } \\
\text { comparison with natural raw material }\end{array}$ \\
\hline
\end{tabular}


Mark evaluation of sensory indices of bilberries frozen by improved technology (with

Figure 6 cryoprotectors)

\begin{tabular}{|c|c|c|l|}
\hline Indices & $\begin{array}{c}\text { Coefficient of } \\
\text { weight }\end{array}$ & Points & \multicolumn{1}{|c|}{ Characteristics } \\
\hline Appearance & 0.35 & 5 & $\begin{array}{l}\text { The berries are clean, evenly frozen, turgid, } \\
\text { with bluish plaque, peels undamaged and } \\
\text { shape kept; suitable for long-term frozen } \\
\text { storage }\end{array}$ \\
\hline Taste & 0.2 & 5 & $\begin{array}{l}\text { Identical to natural fresh berries; without } \\
\text { strange smacks }\end{array}$ \\
\hline Color & 0.1 & 5 & $\begin{array}{l}\text { Intensive, saturated, slightly amplified in } \\
\text { comparison to fresh berries - evidently as } \\
\text { the consequence of anthocyanine synthesis } \\
\text { as the result of the chill stress }\end{array}$ \\
\hline Surface state & 0.2 & 5 & $\begin{array}{l}\text { Without damages, defects, cracks, changes } \\
\text { in shape, and cellular juice losses }\end{array}$ \\
\hline Odor & 0.15 & 5 & $\begin{array}{l}\text { Immanent to fresh berries, but more } \\
\text { intensive due to the synthesis of odorants as } \\
\text { the result of the chill stress }\end{array}$ \\
\hline
\end{tabular}

The results of the experiments showed that bilberries frozen by the traditional technology had not gotten the maximal mark by any of the sensory index; according to our own elaborated recommendations, they are suitable only to short-term (one month) storage. Therefore, they should not be used in winter-and-spring period (with absence of fresh fruit and berries) as the source of vitamins and other valuable components.

On the contrary, bilberries frozen with cryoprotectors had gotten the maximal 5 points by all of the sensory indices; consequently, they had the status of the reliable source of vitamins and mineral elements (in the inter-seasonal period until the new harvest) confirmed.

The increase of the quality of frozen berry half products and the achievement of high sensory indices are the results of the ability of the researched cryoprotectors to lower the amount of frozen water. Correspondingly, the decrease of the number of ice crystals (which are the main factor of cryogenous damages of plant cells) benefits the formation of smallcrystal glacial structure. According to the authors [9], such structure is different by its weak strength fields, which would essentially reduce the grade of mechanical destruction of cytoplasm substances and cellular membranes, and, subsequently, retain their holity during freezing, frozen storage, and defrosting.

\section{Conclusions}

1. Protection of the berries to freeze with all of the researched cryoprotectors allowed accomplishing one of the most important tasks for novel food technologies - to minimize the ruining action of minus temperatures. As the consequence, we could retain over 70 percents of ascorbic acid in frozen berries after their 12-month frozen storage. Meanwhile, traditional freezing technologies (without cryoprotectors) permitted to keep 
the ascorbic acid amount in frozen and defrosted berries on the level of only ca. 30 percents, relatively to this index in fresh berries.

2. The effects achieved are confirmed as the result of the action of the certain substances in cryoprotective complexes (water solutions, first of all) containing various organic and inorganic components - glucose, fructose, sucrose; citric, sorbic and benzoic acids; magnesium chloride. The positive effect of procession of berries by cryoprotectors before freezing may be explained, relying on theoretic knowledge about the protectors' impact on cellular suspensions, obtained in cryobiology. Likewise, we can affirm that the presence of cryoprotectors can change the physical-and-chemical properties, so that the subsiding influences of low temperatures during freezing get less pernicious for cellular structures of the berries processed beforehand. The usage of cryoprotective methods aimed at overtaking the disadvantages of the traditional technologies is the perspective trend of improvement of plant raw preservation with usage of artificial cold.

\section{References}

1. Frozen fruit market in the EU: Germany remains the largest importer,

Available at: https://www.freshplaza.com/article/9020192/frozen-fruit-market-in-theeu-germany-remains-the-largest-importer.

2. Svitovyj popy`t na zamorozheni produkty` prodovzhuye zrostaty Available at: http://www.lol.org.ua/rus/showart.php?id=114914

3. Pranav Goyal, Animesh Verma, Amarnath Joshi (2000), Nutritive value of fruits, vegetables, and their products in postharvest technology of fruits and vegetables. Indus Publishing, New Delhi, pp. 337-389.

4. Joy C. Rickman, Diane M. Barrett, Christine V. Bruhn (2007), Nutritional comparison of fresh, frozen and canned fruits and vegetables. Part 1. Vitamins $\mathrm{C}$ and B and phenolic compounds, Journal of Sci. Food Agric., 87, pp. 930-944.

5. Frozen Foods Handling,

Available at:

http://www.cold.org.gr/library/downloads/Docs/FrozenFoodsHandling.pdf

6. Cristina L.M. Silva, Elsa M. Gonçalves, Teresa R.S. Brandão (2008), Freezing of Fruits and Vegetables. In: J. A. Evans (eds), Frozen Food Science and Technology. Blackwell Publishing Ltd., Oxford, UK, pp. 165-183.

7. Galina O. Simakhina, Nataliia V. Naumenko (2011), Nyz`ki temperatury` v texnologiyax ozdorovchyx produktiv: monografia, Stal, Kyiv.

8. Begona DeAncos, Concepcion Sanchez-Moreno, Sonia de Pascual-Teresa, Maria Pilar Cano (2012), Freezing preservation of fruits. Handbook of Fruits and Fruit Processing, Wiley-Blackwell, Oxford, UK, pp. 103-119.

9. Apollon M. Belous, Vladimir I. Grischenko (1994), Kriobiologiya: monografia, Naukova dumka, Kiev.

10. Mariana-Atena Poiana, Diana Moigradean, Diana Raba, Liana-Maria Alda, VioricaMirela Popa (2010). The effect of long-term frozen storage on the nutraceutical compounds, antioxidant properties and color indices of different kinds of berries, Journal of Food, Agriculture \& Environment, 8(1), pp. 54-58.

11. Olesia P. Priss, Valentina F. Zhukova (2015), Zberezhennya plodiv tomativ i percziu za obrobky ekstraktamy korenya xronu, Xarchova nauka i texnologiya, 5, pp. 68-74. 
12. Rayisa Yu. Pavlyuk, Viktoriya V. Pogarska (2013), Nove v texnologiyi otrymannya zamorozhenyx yahid ta pyure z rekordnymy kharakterystukamy, Progresyvni texnika ta texnologiyi xarchovyx vyrobnycztv restorannogo gospodarstva, 1(1), pp. 3-9.

13. Bing Li, Da Wen Sun (2002), Novel methods for rapid freezing and thawing of foods: A Review, Journal of Food Engineering, 54(3), pp. 175-182.

14. Christopher T. Wagner, Melissa L. Martowicz, Stephen A. Livesey, Jerome Connor (2002), Biochemical stabilization enhances red blood cell recovery and stability following cryopreservation, Cryobiology, 45(2), pp. 153-166.

15. Natalia G. Kadnikova (1992), Zavisimost` krioustoychivosti Bifidobacterium bifidum 1 ot fazy rosta i svojstv kriokonservanta, Dejstviye xoloda na biologicheskiye obyekty. Sbornik nauchnyx trudov, Naukova dumka, Kiev, pp. 26-29.

16. Carrow R.A., MacGrath J.J. (1985), Thermodynamic modeling and cryomicroscopy of cell-size unilamellar and paucilamellar liposomes, Cryobiology, 22, pp. 251-267.

17. Gordiyenko Ye. A., Osetskiy A.I., Rozanov L.F. (1997), Nauchnoye obosnovaniye sposobov nizkotemperaturnogo konservirovaniya kletochnyx suspenzij, Problemy kriobiologiyi, 1, pp. 67-71.

18. Dotsenko N.V. (1998), Kompleks kriozashhity rastitel'nogo syrya pri xolodilnom konservirovaniyi, Odessa.

19. Simakhina G.O., Khalapsina S.V. (2017), Efektyvnist` vykorystannya krioprotektoriv pry zamorozhuvanni dykoroslyx i kultyvovanyx yagid, Naukovi praczi NUHT, 23(3), pp. 179-185.

20. R. Paul Singh, Jatal D. Mannapperuma (1990), Development in Food Freezing. In: Biotechnology and Food Process Engineering. H.G. Schwartzberg, M.A. Rao (eds), Marcel Dekker, New York.

21. Kenneth Helrich (1990), Official methods of analysis of the Association of Official Analytical Chemists, 15, Arlington, Virginia, pp. 1058-1059.

22. Simakhina G.O., Kaminska S.V., Naumenko R.Yu. (2019), Novi pidxody do xarakterystyky i oczinyuvannya osnovnyx organoleptychnyx pokaznykiv svizhyx ta zamorozhenyx plodiv i yagid. Vcheni zapysky Tavriyskogo nacz. universytetu im. V.I. Vernads kogo, 30 (69), №1, pp. 72-78.

23. Belous A.M., Bondarenko V.A. (1982), Strukturnye izmeneniya biologicheskix membran pri oxlazhdeniyi: monografia. Naukova dumka, Kiev.

24. Simakhina G.O., Khalapsina S.V. (2016), Otrymannya zamorozhenyx napivfabrykativ dykoroslyx yagid zi shhil`noyu pokryvnoyu tkanynoyu, Naukovi praczi NUXT, 22, №3, pp. 198-205.

25. Van Buggenhout S., Grauwet T., Van Loey A., Hendrick M. (2008), Structure / processing relation of vacuum infused strawberry tissue frozen under different conditions, European Food Research Technology, 226, pp. 437-448.

26. Yurchenko T., Kozlova V., Skornyakov B. i dr. (1989), Vliyaniye krioprotektorov na biologicheskiye sistemy, Naukova dumka, Kiev.

27. Pushkar N.S., Belous A.M., Itkin Yu.A. i dr. (1994), Nizkotemperaturnaya kristallizatsia v biologicheskix sistemax: monografia, Naukova dumka, Kiev.

28. Noormets M., Karp K., Starast M., Leis L., Muru K. (2006), The influence of freezing on the content of ascorbic acid in Vaccinium species berries, Acta Hort., 715, pp. 539544.

29. Mullen W., Stewart A.J., Lean M.E., Gardner P., Duthie G.G., Crozier A. (2002), Effect of freezing and storage on the phenolics, ellagitannins, flavonoids and antioxidant capacity of red raspberries, J. Agric. Food Chem., 50, pp. 5197-5201. 
30. Sousa M.B., Canet W., Alvarez M.D., Tortosa M.E. (2005), The effect of the pretreatments and the long and short-term frozen storage on the quality of raspberry cv. Heritage, European Food Research and Technology, 221, pp. 132-144.

31. Pellerin-Mendez C., Million L., Marchand-Arvier M etc. (2004), In vitro study of the protective effect of trehalose and dextran during freezing of human red blood cells in liquid nitrogen, Cryobiology, 35, №2, pp. 173-186.

32. Ramazanov V.V., Bondarenko V.A. (2009), Proyavlenie i ustarnenie effekta "upakovki" v sredax s nepronikayushhimi i pronikayushhimi krioprotektorami. Problemy kriobiologiyi, 19(3), pp. 312-323.

33. Ulchibekova N.A., Mukayilov M.D. (2013), Produkty pitaniya vysokoj pischevoj czennosti iz yagod zemlyaniki. Izvestiya vuzov. Pishhevaya texnologiya, 1, pp. 57-59.

34. Howard L.A., Wong A.D etc. (1999), $\beta$-carotene and ascorbic acid retention in fresh and processed vegetables, Journal of Food Science, 64(5), pp. 929-936.

35. Antonio P. Bartolome, Anton Pilar Ruperez, Carmen Fuster Monescillo (1999), Freezing rate and frozen storage on changes of sensory characteristics of pineapple fruit slices, Journal of Food Science, 61(1), pp. 154-163. 